\title{
Chapter 15 \\ Development of Uranium-Free TRU Metallic Fuel Fast Reactor Core
}

\author{
Kyoko Ishii, Mitsuaki Yamaoka, Yasuyuki Moriki, Takashi Oomori, \\ Yasushi Tsuboi, Kazuo Arie, and Masatoshi Kawashima
}

\begin{abstract}
A TRU-burning fast reactor cycle associated with a uranium-free transuranium (TRU) metallic fuel core is one of the solutions for radioactive waste management issue. Use of TRU metallic fuel without uranium makes it possible to maximize the TRU transmutation rate in comparison with uranium and plutonium mixed-oxide fuel because it prevents the fuel itself from producing new plutonium and minor actinides, and furthermore because metallic fuel has much smaller capture-to-fission ratios of TRU than those of mixed-oxide fuel. Also, adoption of metallic fuel enables recycling system to be less challenging, even for uranium-free fuel, because a conventional scheme of fuel recycling by electrorefining and injection casting is applicable.

There are some issues, however, associated with a uranium-free TRU metallic fuel core: decrease in negative Doppler reactivity coefficient from the absence of uranium-238, which has the ability to absorb neutrons at elevated temperatures, increase in burn-up swing, because fissile decreases monotonically in uranium-free core, and so on. The purpose of this paper is to evaluate the feasibility of the uranium-free TRU metallic fuel core by investigating the effect of measures taken to enhance Doppler reactivity feedback and to reduce burn-up swing. The results show a TRU-burning fast reactor cycle using uranium-free TRU metallic fuel is viable from the aforementioned points of view because the introduction of diluent $\mathrm{Zr}$ alloy, spectrum moderator $\mathrm{BeO}$, and lower core height enables Doppler reactivity coefficient and burn-up reactivity swing of uranium-free TRU metallic fuel to be as practicable as those of conventional fuel containing uranium.
\end{abstract}

Keywords Burn-up swing • Doppler reactivity feedback • Fast reactor • Metallic fuel • Trans-uranium • Uranium-free

K. Ishii • M. Yamaoka $・$ Y. Moriki $・$ T. Oomori $\bullet$ Y. Tsuboi $・$ K. Arie $(\triangle)$

Toshiba Corporation, 8 Shinsugita-Cho, Isogo-Ku, Yokohama 235-8523, Japan

e-mail:kazuo.arie@toshiba.co.jp

M. Kawashima

Toshiba Nuclear Engineering Service Corporation, 8 Shinsugita-Cho, Isogo-Ku, Yokohama 235-8523, Japan 


\subsection{Introduction}

For sustainable nuclear power deployment, not only ensuring its enhanced safety but also reduction of the environmental burden associated with radioactive waste management is a challenging issue for the international community. History has shown that obtaining public support is difficult for waste management plans that involve mass disposal of radioactive waste with a half-life of tens of thousands of years. Therefore, as one of the solutions, Toshiba has been developing a system that takes into account that, for the time being, light water reactors (LWRs) have a leading role in commercial nuclear power plants, which enables toxicity and radioactivity of high-level waste to be reduced to those of natural uranium within a few hundred years. This system is mainly characterized by a fast reactor core that does not contain uranium in its fuel, that is, uranium-free TRU fuel. The use of uranium-free TRU fuel makes it possible to maximize the TRU transmutation rate in comparison with fuel containing uranium because it prevents the fuel itself from producing new plutonium and minor actinides.

Although there was much research focused on TRU transmutation with uraniumfree fuels, each of these seems to have drawbacks from some aspect. First, for instance, candidates such as Tc-based and W-based oxide fuel, inert matrix fuel such as the rock-like oxide fuel containing mineral-like compounds, and $\mathrm{MgO}$-based oxide fuel provide solutions against issues associated with uraniumfree operation, that is, decrease in Doppler reactivity feedback and increase in sodium void reactivity [1-3], but such types of inert matrix fuel may require new technologies for reprocessing. Additionally, many processing phases necessary for fabrication are costly. Second, an accelerator-driven transmutation system coupled with a fast reactor using uranium-free metallic fuel is another candidate that also can relax the issue of the reduced Doppler effect owing to its subcritical system [47], but installation of the accelerator facility at a fast reactor site is less cost competitive, especially when the system is not only a TRU burner but also a commercial power plant. Thus, it is worthwhile to develop the TRU transmutation system with uranium-free TRU fuel from the aspect of technological maturity and simplicity, which results in lower cost. Subsequently, the concepts for the TRU burner system with uranium-free TRU are derived from this background: fewer R\&D needs and a simple system.

First, by contrast with inert matrix fuels, metallic fuel can be fabricated by the well-known injection casting method [8]. Moreover, metallic fuel is compatible with pyro-process reprocessing that has been developed since the 1960s [9]. Application of an accelerator-driven system for transmutation needs further R\&D than that of a fast reactor system. Thus, the metallic fuel fast reactor is preferred for the system.

Second, we aim to develop the TRU-burning system in commercial power reactors while avoiding cost impact. For this reason, a system that can employ the pyro-process for fuel reprocessing would be preferable because it does not need 


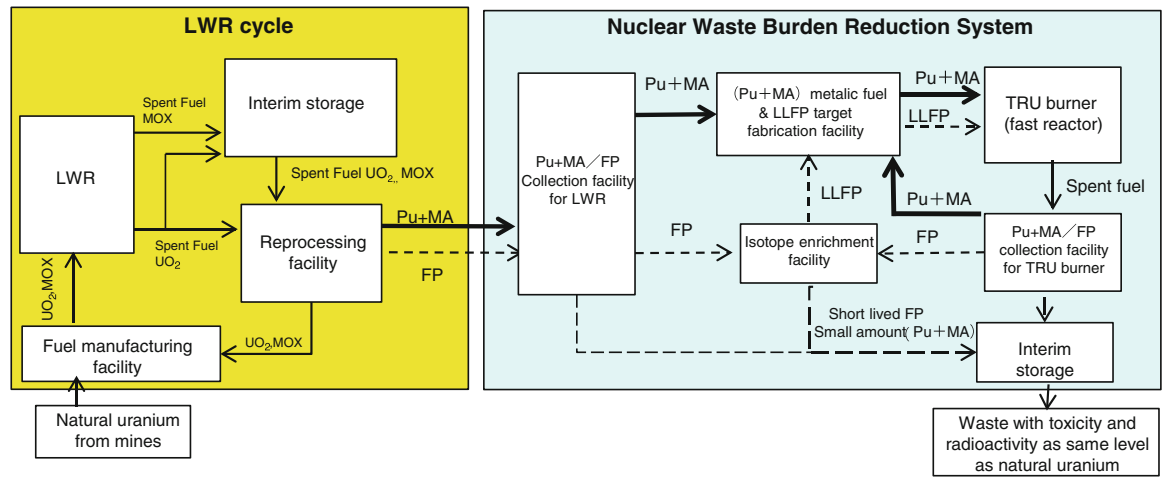

Fig. 15.1 Configuration diagram of the system to reduce nuclear waste burden

complex processes. Therefore, we introduce a metal fuel alloy that can be simply fabricated by injection casting and reprocessed by pyro-processing.

Additionally, in terms of reduction of nuclear waste burden, a metallic fuel fast reactor cycle has the great potential to transmute long-lived fission products (LLFPs) because of its excellent neutron economy [10, 11]. Moreover, it has an advantage for long-term energy security because the basic technology of the metallic fuel fast reactor cycle is also applicable to the future sustainable nuclear energy supply system.

For these reasons, Toshiba is developing a system to reduce nuclear waste burden using a TRU burner as shown in Fig. 15.1. The system is characterized by a closed fuel cycle that encompasses the following main facilities: fuel manufacturing plant to fabricate uranium-free TRU metallic fuel and LLFPs target from TRU and LLFPs extracted from LWR spent fuel, a fast reactor to burn those fuels, and recycling facilities to reprocess and refabricate the spent fuel from the fast reactor by pyroprocessing. Although substances remain after reprocessing that must finally be disposed outside the cycle, their toxicity and radioactivity are diminished to the same level as those of natural uranium by enhancing burning and processing rates and storing them for a few hundred years within the system. Among the aforementioned facilities in the system, this study focuses on the TRU-burning fast reactor and investigates the practicability of the uranium-free TRU metallic fuel core.

\subsection{Issues and Measures Against the Uranium-Free TRU Metallic Fast Reactor Core}

This chapter presents issues and measures against the uranium-free TRU metallic fast reactor core. Also, the targets and constraints in parametric survey and selection of core and fuel specification are briefly described. 
There are two main issues associated with the TRU burning fast reactor cycle using uranium-free metallic fuel in terms of practicability:

(1) Decrease in the absolute value of the negative Doppler reactivity coefficient resulting from absence of uranium-238, which has the ability to absorb neutrons at elevated temperatures. example,

metallic fuel with uranium: $-1 \times 10^{-3} \mathrm{Tdk} / \mathrm{dT}$

metallic fuel without uranium: $-6 \times 10^{-4} \mathrm{Tdk} / \mathrm{dT}$

(2) Increase in burn-up reactivity swing as fissile decreases monotonically in uranium-free core. example,

metallic fuel with uranium: $\sim 1 \% \mathrm{dk} / \mathrm{kk}^{\prime} / 150$ days

metallic fuel without uranium: $\sim 6 \% \mathrm{dk} / \mathrm{kk}^{\prime} / 150$ days

To solve these issues, there are several candidates, as follows:

(1) Enhance Doppler feedback

- Introduce diluent material in the metallic fuel

- Introduce spectrum moderator

(2) Reduce burn-up reactivity swing

- Reduce the core height

- Introduce neutron absorber outside the core

- Increase the number of refueling batches

Generally, if it is conventional fast reactors with U-Pu fuel, the burn-up reactivity swing depends mainly on decrease of fissile amount and increase of neutron parasitic capture of fission products and actinides from burn-up. Therefore, the typical ways to reduce burn-up reactivity swing are to increase conversion ratio via fissile enrichment reduction and to reduce neutron parasitic capture. Here, the conversion ratio is defined as the amount of fissile materials production divided by the amount of neutron absorption, that is, fission and capture, and natural decay of fissile materials. It is difficult, however, for a uranium-free core to increase the conversion ratio because fissile enrichment cannot be controlled in the absence of uranium. Although the reduction of neutron parasitic capture by neutron spectrum hardening improves burn-up reactivity swing, it also harms the Doppler effect. For these reasons, when it comes to uranium-free core, increase of the fissile amount at the beginning of the cycle makes sense because it reduces the ratio of the fissile consumption to the fissile amount at the beginning of the cycle.

These candidates were parametrically surveyed to evaluate the feasibility of the uranium-free TRU metallic fuel fast reactor core in light of aforementioned issues. The targets assumed were the core performances with the Doppler reactivity coefficient equivalent to a conventional $\mathrm{U}-\mathrm{Pu}$ metallic fuel core. Furthermore, constrains associated with fuel fabrication such as melting temperature was taken into consideration because, in this evaluation, diluent material was assumed to be used as a fuel slug alloy, not cladding material. Hence, the slug was assumed be 
Table 15.1 Assumed condition of the $300 \mathrm{MWe}$ fast reactor core for the parametric survey

\begin{tabular}{l|l}
\hline Items & Value \\
\hline Reactor thermal power & $714 \mathrm{MW}$ \\
\hline Operation cycle length & 150 days \\
\hline Fuel type & TRU $10 \mathrm{wt} \% \mathrm{Zr}$ alloy \\
\hline Number of fuel pins per S/A & 169 \\
\hline Core diameter & $180 \mathrm{~cm}$ \\
\hline Fuel pin diameter & $0.65 \mathrm{~cm}$ \\
\hline Core height & $93 \mathrm{~cm}$ \\
\hline TRU composition & LWR discharged \\
\cline { 2 - 2 } & 10 years cooled \\
\hline
\end{tabular}

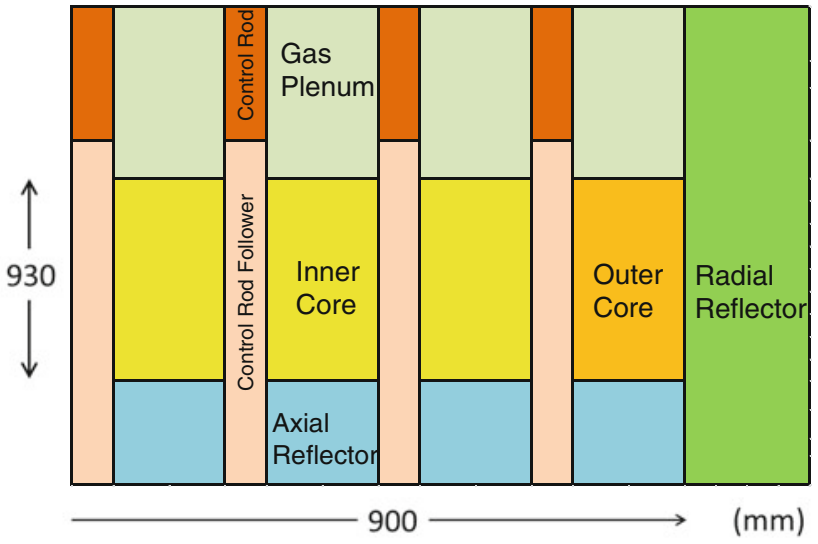

Fig. 15.2 RZ geometry for parametric survey

fabricated by injection casting as the same as the conventional metallic fuel. This step makes the allowable maximum melting temperature of the fuel alloy less than $1,200{ }^{\circ} \mathrm{C}$ to prevent Am volatilization during injection casting [12].

\subsection{Parametric Analysis on the Effect of Measures}

This chapter describes parametric analysis methodology and analysis results for Doppler feedback enhancement and burn-up reactivity swing reduction.

\subsubsection{Parametric Analysis Methodology}

A hypothetical $300 \mathrm{MWe}$ fast reactor core was used for the parametric survey to enhance Doppler feedback and burn-up reactivity swing. Table 15.1 and Fig. 15.2 
show the assumed core conditions and RZ geometry for parametric survey, respectively. The calculation methods were as follows. Core burn-up characteristics were analyzed with the burnup calculation code STANBRE [13]. Reactivity coefficients were analyzed using the diffusion calculation code DIF3D [14]. The effective cross sections used in these calculations were obtained by the cell calculation code SLAROM-UF [15], based upon 70 group cross sections from JENDL-4.0 [16] with a self-shielding factor table as a function of background cross section. This method for the production of the effective cross sections is considered to be adequate to take into account the influence of each diluting material upon the self-shielding effect of heavy isotopes for the parametric study. Concerning material compositions, a homogeneous model of fuel, diluent, and spectrum moderator was used.

To begin with, in the survey to improve Doppler feedback, 21 elements to enhance resonance absorption were evaluated as a diluent material for the TRU alloy: $\mathrm{Cr}, \mathrm{Mn}, \mathrm{Fe}, \mathrm{Ni}, \mathrm{Nb}, \mathrm{Mo}, \mathrm{Tc}, \mathrm{Ru}, \mathrm{Rh}, \mathrm{Pd}, \mathrm{Nd}, \mathrm{Sm}, \mathrm{Gd}, \mathrm{Tb}, \mathrm{Dy}, \mathrm{Er}, \mathrm{Tm}, \mathrm{Ta}, \mathrm{W}$, $\mathrm{Os}$, and $\mathrm{Au}$. Moreover, the effect by neutron moderators such as $\mathrm{BeO},{ }^{7} \mathrm{Li}_{2} \mathrm{O},{ }^{11} \mathrm{~B}_{4} \mathrm{C}$ (100\% enrichment of ${ }^{11} \mathrm{~B}$ was assumed), and $\mathrm{ZrH}_{2}$ were investigated to clarify the impact against Doppler feedback by neutron spectrum softening. To compare the Doppler effect enhancement of various diluent materials and neutron spectrum moderators in a simple manner, each material was hypothetically added to TRU-10wt $\%$ Zr alloy. The amount of each material added was adjusted case by case to maintain 1.0 of k-effective at the end of cycle.

Next, in the evaluation to decrease the burn-up swing, the effects of the measures taken to increase the fissile amount at the beginning of the cycle were studied. The effects on burn-up reactivity swing were evaluated by reducing the core height, installing $\mathrm{B}_{4} \mathrm{C}$ shield at core peripheral, and increasing the number of refueling batches, which all lead to increase of the fissile amount at the beginning of the cycle.

Last, reflecting the results obtained by the parameter surveys, an optimal uranium-free TRU metallic fuel core was specified, and its feasibility in light of Doppler feedback and burn-up swing was evaluated by core performance analysis.

\subsubsection{Analysis Results for Doppler Feedback Enhancement}

The effects of measures taken to enhance Doppler feedback, that is, diluent and spectrum moderator, are evaluated in this section.

As shown in Fig. 15.3, 6 among 21 diluent materials are found to enhance Doppler feedback more than $\mathrm{Zr}$, the typical metallic fuel alloy. Although $\mathrm{Nb}$, $\mathrm{Ni}, \mathrm{W}, \mathrm{Mo}, \mathrm{Fe}$, and $\mathrm{Cr}$ have greater potential to enhance Doppler feedback than $\mathrm{Zr}$, there are some deficiencies that cannot be ignored. First, the melting points of $\mathrm{Pu}-\mathrm{Ni}$ alloy and $\mathrm{Pu}-\mathrm{Fe}$ alloy are below $500{ }^{\circ} \mathrm{C}$, which is too low for nuclear fuel [17]. Second, the melting point of $\mathrm{Pu}-\mathrm{W}$ alloy is too high to fabricate fuel by injection casting because the melting temperature of $\mathrm{W}$ itself is above $3,000{ }^{\circ} \mathrm{C}$. 


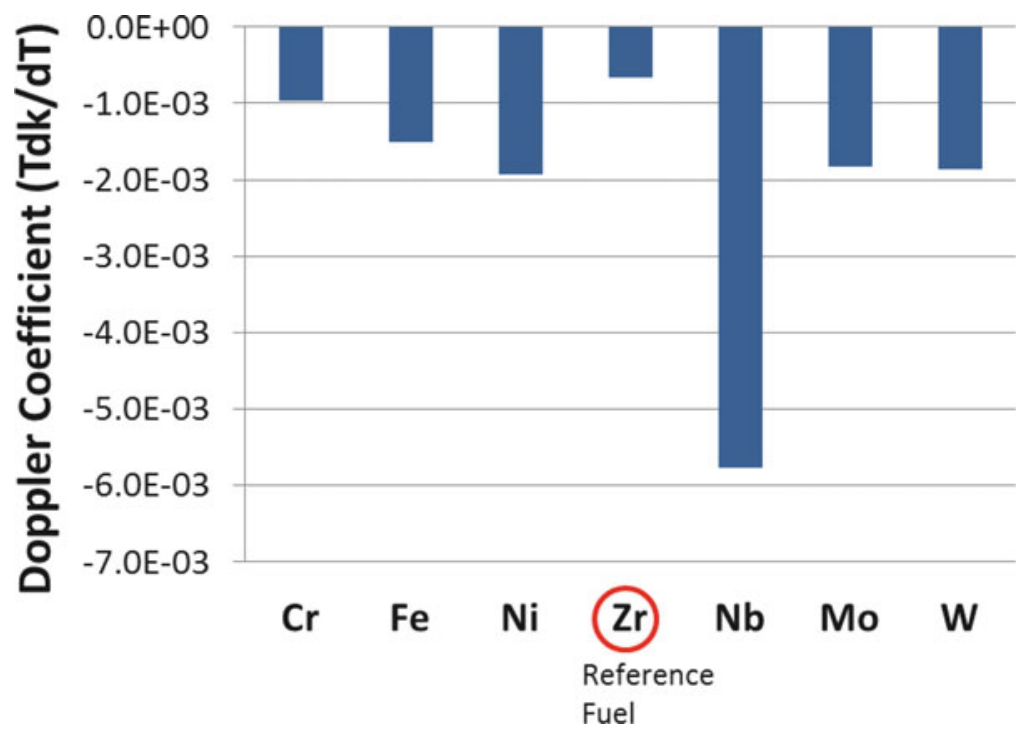

Fig. 15.3 Doppler coefficients associated with major diluent elements

Third, the allowable contents of Mo and $\mathrm{Nb}$ in the metal fuel alloy are too small to enhance the Doppler coefficients, which are $5 \mathrm{wt} \%$ and $3 \mathrm{wt} \%$, respectively, under the condition to maintain their melting temperatures below $1,200{ }^{\circ} \mathrm{C}$ to prevent $\mathrm{Am}$ vaporization during injection casting [18]. Finally, the number of past experiences with $\mathrm{Cr}$, for example, irradiation testing of $\mathrm{Pu}-\mathrm{Cr}$ alloy, is less than enough to employ it as a diluent material for uranium-free fuel. Consequently, $\mathrm{Zr}$ was chosen as the fuel diluent material.

Then, as shown in Fig. 15.4, the absolute value of the negative Doppler coefficient remarkably increased by introducing a spectrum moderator such as $\mathrm{BeO}$, ${ }^{11} \mathrm{~B}_{4} \mathrm{C}$, or $\mathrm{ZrH}_{2}$. The adoption of $\mathrm{ZrH}_{2}$, however, may cause dissociation of hydrogen upon accident. Besides, the usage of ${ }^{11} \mathrm{~B}_{4} \mathrm{C}$ is costly because almost $100 \%$ enrichment of ${ }^{11} \mathrm{~B}$ is necessary to enhance Doppler feedback significantly. Therefore, $\mathrm{BeO}$ was selected as a moderator material for the uranium-free core.

\subsubsection{Analysis Results for Burnup Reactivity Swing Reduction}

This section evaluates the effects of measures taken to reduce burnup reactivity swing of the uranium-free TRU metallic fuel core. In the parameter surveys, the operation cycle length, that is, 150 days, the core volume, and the core power density were kept constant to compare the effect of each countermeasure. The average fuel burnup was also kept constant, save for the survey of the number 


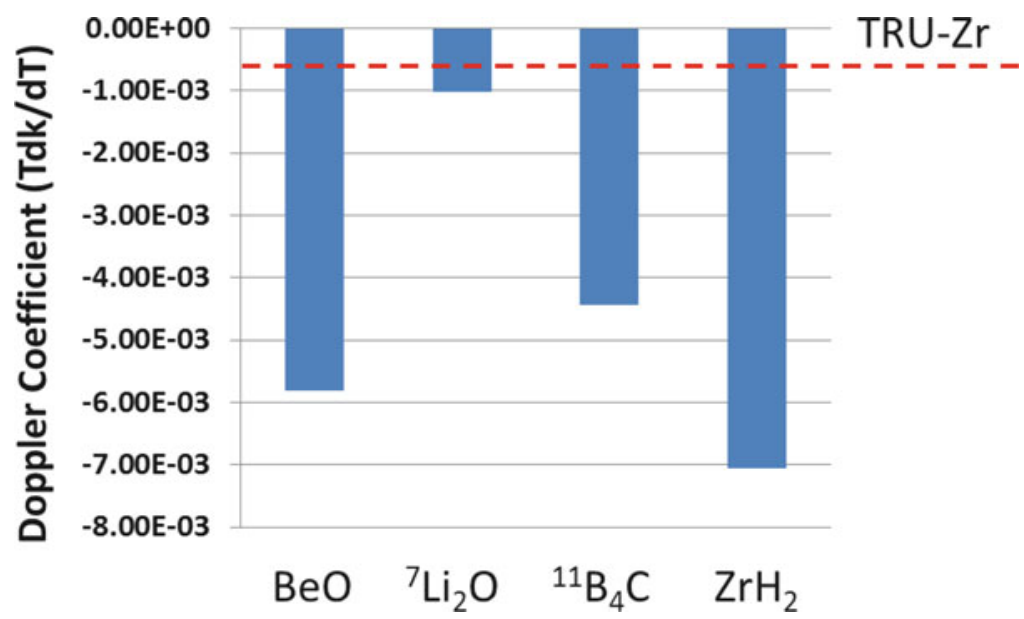

Fig. 15.4 Doppler coefficients associated with neutron spectrum moderator

Table 15.2 Results of burn-up reactivity swing reduction

\begin{tabular}{l|l}
\hline Items & Reduction (\%) \\
\hline Core height changed from 93 to $65 \mathrm{~cm}$ & 12 \\
\hline Peripheral S/A reflector changed to $\mathrm{B}_{4} \mathrm{C}$ absorber & 5 \\
\hline Number of refueling batches changed from 5 to 7 & 5 \\
\hline
\end{tabular}

of refueling batches. The adjusting parameter to increase the fissile amount was the zirconium content in TRU-Zr alloy fuel to keep k-effective $=1.0$ at the end of the cycle.

Table 15.2 shows the summary of the analysis results. The reduction of the core height from $93 \mathrm{~cm}$ to $65 \mathrm{~cm}$ resulted in a $12 \%$ decrease of burn-up reactivity swing. The introduction of a $\mathrm{B}_{4} \mathrm{C}$ shield, where natural boron was assumed, at the core periphery region resulted in only about a $5 \%$ decrease in burn-up reactivity swing. On the other hand, the penalty of this countermeasure is the increase of core power peaking because the leakage of neutrons from the core surface increases. Hence, this measure was not adopted in the subsequent core design. Regarding the effect of the number of refueling batches, the larger is the number of refueling batches, the smaller the burn-up reactivity swing becomes. The effect was approximately a $5 \%$ decrease in burnup reactivity swing for a $40 \%$ increase in the number of refueling batches. This measure was not adopted in the subsequent core design because its effect on the burn-up reactivity swing is small and it leads to significant increase of core power peaking because of the increased difference of burn-up between most burnt fuel and fresh fuel. 
Table 15.3 Specification of the uranium-free TRU metallic core

\begin{tabular}{l|l}
\hline Items & Value \\
\hline Reactor thermal power & $714 \mathrm{MW}$ \\
\hline Operation cycle length & 150 days \\
\hline Fuel type & TRU-Zr alloy \\
\hline Number of fuel pins per S/A & 135 \\
\hline Fuel pin diameter & $0.48 \mathrm{~cm}$ \\
\hline Core diameter & $250 \mathrm{~cm}$ \\
\hline Core height & $65 \mathrm{~cm}$ \\
\hline Spectrum moderator & BeO pins in Fuel S/A (number of pins, 196) \\
\hline TRU composition & LWR discharged \\
\cline { 2 - 2 } & 10 years cooled \\
\hline
\end{tabular}

\subsection{Developed Uranium-Free TRU Metallic Core}

This chapter describes specifications for selection of a uranium-free TRU metallic core and performance of the uranium-free TRU metallic core. Then, the core and fuel are developed on the basis of those results and the feasibility of the developed core is evaluated.

\subsubsection{Specification Selected for Uranium-Free TRU Metallic Core}

On the basis of the results of the parametric surveys, the uranium-free TRU burning core was specified as shown in Table 15.3 and Fig. 15.5. TRU-Zr alloy fuel pins and $\mathrm{BeO}$ pins were employed to enhance the Doppler coefficient. The reason for adopting the TRU-Zr alloy fuel is to use a simpler fuel fabrication method, that is, injection casting, in contrast to a TRU-Zr particle fuel in a zirconium metal matrix. Then, the zirconium content in TRU-Zr alloy was assumed to be limited below $35 \mathrm{wt} \%$ to keep the melting point of the TRU-Zr alloy below $1,200{ }^{\circ} \mathrm{C}$ to prevent Am vaporization during injection casting [19]. The fuel pins and the $\mathrm{BeO}$ pins were separately located in the fuel subassemblies (Fig. 15.6). The diameter of fuel pins was reduced from 0.65 to $0.48 \mathrm{~cm}$ to compensate for the increase of the average linear heat rate caused by employment of the $\mathrm{BeO}$ pins. Core height is $65 \mathrm{~cm}$ to reduce burn-up reactivity swing, whereas the core diameter was increased from 180 to $250 \mathrm{~cm}$ to keep the linear heat rate of the fuel pin similar to the $93-\mathrm{cm}$ height core. The operation cycle length is 150 days, which can be controlled by conventional control rods and fixed neutron absorbers. 


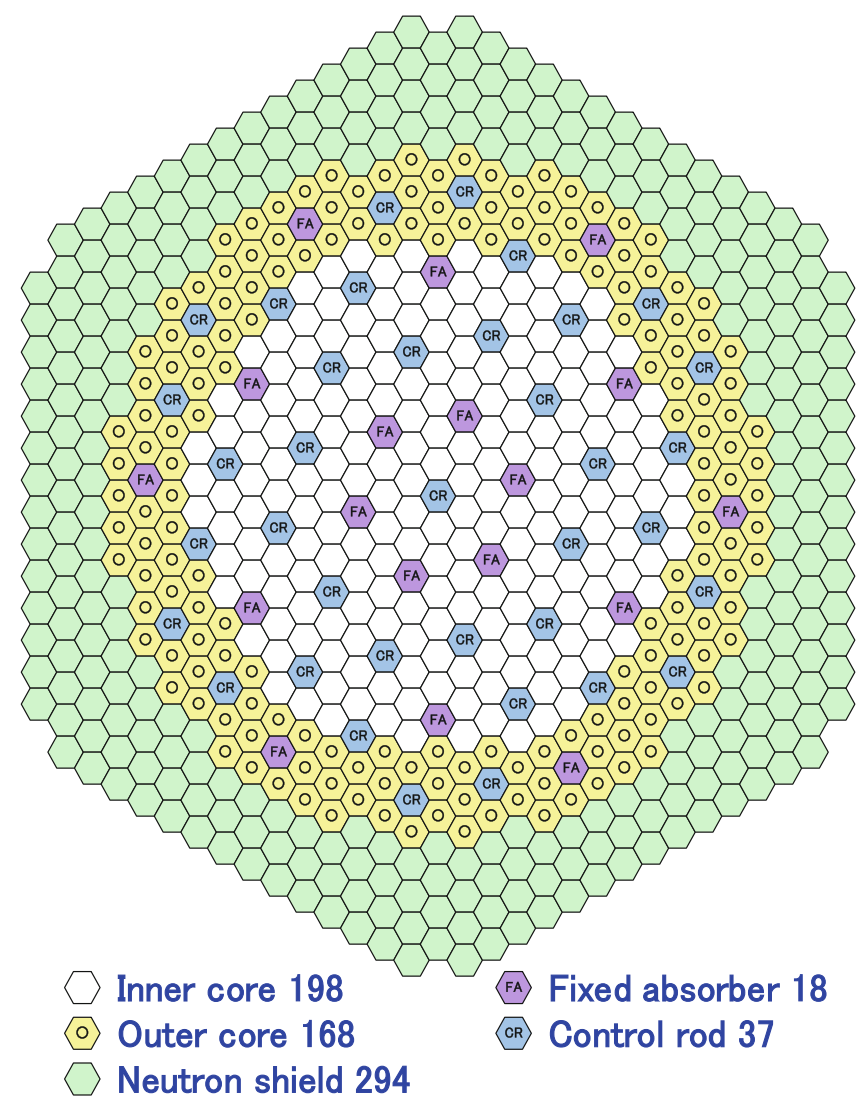

Fig. 15.5 Uranium-free core layout

\subsubsection{Performance of the Uranium-Free TRU Metallic Core}

The core performance of the developed uranium-free core was evaluated as shown in Table 15.4. The $\mathrm{Zr}$ content in the fuel alloy was determined to maintain criticality during the operation cycle under the conditions of the upper limit of the melting point, $1,200{ }^{\circ} \mathrm{C}$. According to the results, the uranium-free TRU metallic core is viable in terms of core performance, safety performance, fuel fabrication, and TRU burner.

The Doppler coefficient is similar to that of the conventional metallic fuel fast reactor cores, and the burn-up reactivity swing is considered to be controllable by conventional control rods and fixed absorbers. Moreover, core sodium void reactivity including the upper plenum region is negative because of neutron leakage at the upper plenum region and neutron spectrum moderation from the presence of $\mathrm{BeO}$ during sodium voiding. Although the restriction for sodium void reactivity 


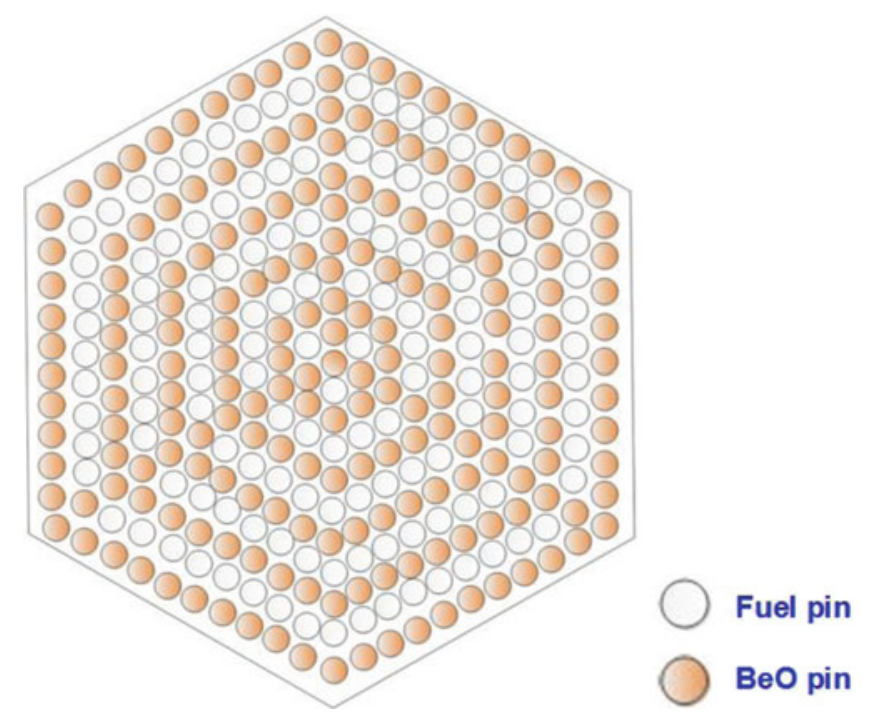

Fig. 15.6 Fuel subassembly cross section

Table 15.4 Performance of the uranium-free TRU metallic core

\begin{tabular}{l|l}
\hline Items & Value \\
\hline Fuel composition & TRU-35\%Zr/TRU-19\% $\mathrm{Zr}$ \\
\hline Inner core/outer core & \\
\hline TRU inventory (Pu/MA) & $2.17 \mathrm{t}$ at BOEC $(1.89 / 0.28 \mathrm{t})$ \\
\hline Burn-up reactivity swing & $5.1 \% \mathrm{dk} / \mathrm{kk}^{\prime}$ \\
\hline Power density (average) & $260 \mathrm{~W} / \mathrm{cc}$ \\
\hline Linear heat rate (average) & $220 \mathrm{~W} / \mathrm{cm}$ \\
\hline TRU burning rate $(\mathrm{Pu} / \mathrm{MA})$ & $260 \mathrm{~kg} / \mathrm{EFPY}(230 / 30 \mathrm{~kg} / \mathrm{EFPY})$ \\
\hline Doppler coefficient at EOEC & $-3 \times 10^{-3} \mathrm{Tdk} / \mathrm{dT}$ \\
\hline Na void reactivity at EOEC & $<0 \% \mathrm{dk} / \mathrm{kk}^{\prime}$
\end{tabular}

$E O E C$ end of equilibrium cycle, $E F P Y$ effective full-power year

was not assumed for the core in this study, low sodium void reactivity is a significant factor for sodium-cooled fast reactors.

Furthermore, the developed core design has the potential to achieve passive safety features against unprotected events such as unprotected loss of flow (ULOF) and unprotected transient overpower (UTOP) similar to a conventional metallic fuel core because the basic core safety parameters, that is, average and peak linear heat rates for lower fuel temperatures, the enhanced Doppler coefficient, and low sodium void coefficient (negative sodium coefficient in whole core), were maintained within the similar ranges of a conventional metallic fuel core design [20]. 
Feasibility in the light of decay heat is also confirmed to be practicable, as the decay heat of the fresh fuel material is $32 \mathrm{~W} / \mathrm{kgHM}$, which is less than $10 \%$ of that of the minor actinide (MA)-only fuel. Also, the decay heat of the fresh fuel subassembly is approximately $240 \mathrm{~W}$. Taking advantage of some cooling scheme such as air flow, this fuel can be fabricated as a fuel pin bundle [21].

Moreover, the results also shows the profitability of the uranium-free TRU metallic fuel fast reactor itself, because a 1-year operation of this $300 \mathrm{MWe}$ TRU-burning fast reactor burns $260 \mathrm{~kg}$ TRU, corresponding to the amount produced by a 1.2 GWe-year operation of a conventional LWR.

For all these reasons, the TRU-burning fast reactor using uranium-free TRU metallic fuel is considered to be feasible. Further study such as reduction of burn-up reactivity swing and trade-off of various countermeasures considering economic aspect helps improve and optimize the core design in the next phase.

\subsection{Conclusions}

A TRU transmutation system associated with the uranium-free metallic fuel fast reactor is a practical way to burn TRU with sustainability, fewer R\&D needs, and a simple system, because it can be used as both a TRU burner and a power supply plant. Employment of pyro-processing for recycling reduces the burden of R\&D requirements, and introduction of a conventional fuel fabrication method and pyroprocessing allows less complex facilities.

In this study, two main issues related to the uranium-free core were investigated and discussed to clarify the feasibility of a TRU-burning fast reactor cycle using such a core: Doppler coefficient for reactor safety, and burn-up reactivity swing for acceptable reactor operating cycle length.

The results show that the uranium-free fast TRU fast reactor core is viable because those issues can be solved by TRU-Zr alloy fuel, $\mathrm{BeO}$ neutron moderator, and reduced core height. Thanks to the $\mathrm{BeO}$ pins that function not only as a neutron moderator but also as a diluent material, the $35 \% \mathrm{Zr}$ alloy fuel can be fabricated without Am vaporization because its melting point is maintained below $1,200{ }^{\circ} \mathrm{C}$, the temperature that causes Am vaporization during injection casting fuel fabrication. Moreover, the decay heat of the fresh fuel is considered to be an acceptable level for the fuel fabrication. Also, a 1-year operation of this $300 \mathrm{MWe}$ core burns the TRU that is produced by $1.2 \mathrm{GWe}$-year operation of a conventional LWR.

In conclusion, the prospect of a TRU-burning fast reactor cycle using uraniumfree metallic fuel was confirmed. Further study, not only to improve core performances but also to develop a recycling process associated with this uranium-free system, which is currently under way, promotes realization of the system.

Open Access This chapter is distributed under the terms of the Creative Commons Attribution Noncommercial License, which permits any noncommercial use, distribution, and reproduction in any medium, provided the original author(s) and source are credited. 


\section{References}

1. Yamashita T, Kuramoto K-I, Akie H, Nakano Y, Nitani N, Nakamura T, Kusagaya K, Ohmichi T (2002) Rock-like oxide fuels and their burning in LWRs. J Nucl Sci Technol 39(8):865-871

2. Miwa S, Osaka M, Usuki T, Sato I, Tanaka K, Hirosawa T, Yoshimachi H, Onose S (2011) $\mathrm{MgO}-$ based inert matrix fuel for a minor actinide recycling in a fast reactor cycle. In: Proceedings of Global 2011, Makuhari, Japan, Dec 11-16, 2011

3. Messaoudi N, Tommasi J (2002) Fast burner reactor devoted to minor actinide incineration. Nucl Technol 137:84-96

4. Hill RH, Khalil HS (2000) Physics studies for sodium cooled ATW blanket. In: Proceedings of the IAEA technical committee meeting on core physics and engineering aspects of emerging nuclear energy systems for energy generation and transmutation. Argonne National Laboratory

5. Beller DE, Van Tuyle GJ, Bennett D, Lawrence G, Thomas K, Pasamehtoglu K, Li N, Hill D, Laidler J, Finck P (2001) The U.S. accelerator transmutation of waste program. Nucl Instrum Methods Phys Res A 463:468-486

6. Heidet F, Kim TK, Taiwo TA (2013) Multiple-stage fuel cycle options based on subcritical systems. In: Proceedings of the 2013 ANS Winter Meeting, Washington, DC, November 10 14, 2013

7. Meyer MK et al (2001) Fuel design for the U.S. accelerator driven transmutation system. Nuclear Application in the New Millennium (accApp-ADITTA '01), Reno, Nov 2001

8. Carmack WJ et al (2009) Metallic fuels for advanced reactor. J Nucl Mater 392:139-150

9. Stevenson CE (1987) The EBR-II fuel cycle story. American Nuclear Society, La Grange Park, Illinois, USA

10. Arie K, Kawashima M, Araki Y, Sato M, Mori K, Nakayama Y, Ishiguma K, Fujiie Y (2007) The sustainable system for global nuclear energy utilization. In: GLOBAL 2007, Boise, ID, September 9-13, 2007

11. Arie K, Kawashima M, Oomori T, Okita T, Kotake S, Fujiie Y (2013) Role of fast reactor and its cycle to reduce nuclear waste burden, In: GLOBAL 2013, Salt Lake City, UT, September 29-October 3, 2013

12. Hayes S et al (2009) Status of transuranic bearing metallic fuel development. In: Global 2009, Paris, September 6-11, 2009

13. OECD-NEA (2000) Nuclear Energy Agency, Organisation for Economic and Co-operation Development (NEA, OECD), Paris, France

14. Derstine KL (1984) DIF3D: a code to solve one-,two- and three-dimensional finite difference diffusion theory problems. ANL-82-64, Argonne National Laboratory

15. Hazama T et al (2009) SLAROM-UF: ultra fine group cell calculation code for fast reactor: version 20090113. JAEA-Review 2009-003

16. Shibata K, Iwamoto O, Nakagawa T, Iwamoto N, Ichihara A, Kunieda S, Chiba S, Furutaka K, Otuka N, Ohsawa T, Murata T, Matsunobu H, Zukeran A, Kamada S, Katakura J (2011) JENDL-4.0: a new library for nuclear science and engineering. J Nucl Sci Technol 48(1):1-30

17. Kittel JH et al (1971) Plutonium and plutonium alloys as nuclear fuel materials. Nucl Eng Des 15:373-440

18. ASM Alloy Phase Diagram Center (2007) ASM International, Materials Park. (http://www. asminternational.org/AsmEnterprise/APD)

19. Hecker SS, Stan M (2008) Properties of plutonium and its alloys for use as fast reactor fuels. J Nucl Mater 383:112-118

20. Wade DC, Fujita EK (1989) Trends versus reactor size of passive reactivity shutdown and control performance. Nucl Sci Eng 103:182

21. Kawaguchi $\mathrm{K}$ et al (2007) Conceptual study of measures again heat generation for TRU fuel fabrication system. In: Global 2007, Boise, ID, September 2007 